\title{
PERLINDUNGAN HUKUM PARA PIHAK DALAM PERJANJIAN WARALABA MAKANAN*
}

\author{
Zil Aidi", Hasna Farida \\ Fakultas Hukum, Universitas Diponegoro \\ Jalan Prof. Soedarto, Tembalang, Semarang. \\ "e-mail: zil.aidi93@gmail.com \\ e-mail: hasnaf99@gmail.com
}

\begin{abstract}
This research aimed to find out and analyze the legal protection of the parties in a food franchise agreement. Furthermore, this research also aimed to find out and analyze the efforts that could be taken by the parties in the event of default in the implementation of the Franchise Agreement. The research that made Sukoharjo Branch Bakso Tengkleng Mas Bambang Branch as a respondent was a juridical empirical qualitative research and analyzed the data collected using qualitative descriptive methods. The results of the research showed that the form of legal protection provided was in the form of preventive and repressive legal protection. Preventive legal protection could be seen in the clause contained in the Tengkleng Mas Bambang Meatball Franchise Agreement which contained the obligations of each party, namely in Articles 5 and 6 concerning the obligation to maintain confidentiality, maintain the brand, and comply with established procedures. Preventive legal protection was also stated in Article 1 number 9 and Article 11 of the Franchise Agreement regarding the prohibition to provide food and beverages other than Tengkleng Mas Bambang Meatballs and trade secrets. Repressive legal protection was seen through the provision of resolving disputes through consensus. If the meeting did not succeed in reaching an agreement then both parties could resolve the dispute through litigation. So far, any form of dispute that occured including defaults could still be resolved through deliberation without taking the path of litigation.
\end{abstract}

Keywords: Food Franchise Agreement; Legal Protection.

\begin{abstract}
Abstrak
Penelitian ini bertujuan untuk mengetahui dan menganalisa perlindungan hukum terhadap para pihak dalam perjanjian waralaba makanan. Selanjutnya, penelitian ini juga bertujuan untuk mengetahui dan menganalisa upaya yang dapat ditempuh oleh para pihak dalam hal terjadi wanprestasi dalam pelaksanaan Perjanjian Waralaba tersebut. Penelitian yang menjadikan Bakso Tengkleng Mas Bambang Cabang Sukoharjo sebagai responden ini merupakan penelitian kualitatif yang bersifat yuridis empiris dan menganalisa data yang terkumpul dengan metode deskriptif kualitatif. Hasil penelitian menunjukan bahwa bentuk perlindungan hukum yang diberikan berupa perlindungan hukum preventif dan represif. Perlindungan hukum secara preventif terlihat pada terdapatnya klausula yang terdapat pada Perjanjian Waralaba Bakso Tengkleng Mas Bambang yang memuat mengenai kewajiban masing-masing pihak yakni dalam Pasal 5 dan 6 mengenai kewajiban untuk menjaga kerahasiaan, menjaga merek, dan menaati prosedur yang ditetapkan. Perlindungan hukum secara preventif juga tercantum dalam Pasal 1 angka 9 dan Pasal 11 Perjanjian Waralaba mengenai larangan untuk menyajikan makanan dan minuman lain selain Bakso Tengkleng Mas Bambang serta rahasia dagang. Perlindungan hukum secara represif terlihat melalui adanya ketentuan untuk menyelesaikan perselisihan melalui musyawarah mufakat. Apabila musyawarah tersebut tidak berhasil mencapai kesepakatan maka barulah kedua belah pihak dapat menyelesaikan sengketa melalui jalur litigasi. Sejauh ini, setiap bentuk perselisihan yang terjadi
\end{abstract}

\footnotetext{
* Naskah diterima: 03 Januari 2019, direvisi: 10 Maret 2019, disetujui untuk terbit: 12 Maret 2019

Doi: $10.3376 /$ jch.v4i2.119
} 
termasuk di dalamnya wanprestasi masih dapat diselesaikan melalui musyawarah tanpa menempuh jalur litigasi.

Kata Kunci: Perjanjian Waralaba Makanan; Perlindungan Hukum.

\section{PENDAHULUAN}

Dewasa ini persaingan di dunia bisnis kian ketat. Fenomena ini semakin menyadarkan para pengusaha untuk mencari pendekatan-pendekatan serta terobosan yang inovatif guna merebut pangsa pasar (Setiawan et. al, 2011 : 50) . Agar dapat terus bertahan, ekspansi atau pengembangan usaha menjadi pilihan wajib para pelaku usaha. Berhasil atau tidaknya ekspansi usaha sangat ditentukan oleh efektif atau tidaknya strategi pemasaran yang dilakukan.

Melakukan pemasaran produk secara internasional dengan ekspor impor, pemberian lisensi, menjalankan sistem waralaba, membentuk perusahaan patungan, dan melakukan penanaman modal langsung dengan kepemilikan yang menyeluruh, atau melalui merger, konsolidasi, maupun akuisisi merupakan langkah - langkah yang dapat ditempuh untuk meningkatkan usaha menurut pendapat Warren J. Keegen (Widjaja, 2001: 1). Dari kelima macam cara pengembangan usaha tersebut, waralaba atau franchise merupakan salah satu strategi pemasaran yang banyak digunakan saat ini.

Waralaba adalah sebuah bentuk pengembangan usaha yang melibatkan pemberian izin atau hak untuk memanfaatkan, menggunakan, ataupun melaksanakan hak atas kekayaan intelektual milik pemberi lisensi (Widjaja, 2001: 2).

Definisi yuridis waralaba dapat ditemukan pada Pasal 1 angka (1) Peraturan Pemerintah Republik Indonesia Nomor 42 Tahun 2007 tentang Waralaba mendefinisikan waralaba sebagai berikut:

"Waralaba adalah hak khusus yang dimiliki oleh orang perseorangan atau badan usaha terhadap sistem bisnis dengan ciri khas usaha dalam rangka memasarkan barang dan/atau jasa yang telah terbukti berhasil dan dapat dimanfaatkan dan/atau digunakan oleh pihak lain berdasarkan perjanjian waralaba."

Perkembangan bisnis waralaba (franchise) telah berkembang dengan pesat dan menjadi kekuatan baru bagi sektor ekonomi domestik di Indonesia. Maraknya perdagangan barang dan jasa dengan sistem waralaba tersebut, karena sistem tersebut lebih menguntungkan baik bagi pemberi waralaba maupun penerima waralaba (Idrus, 2017: 28). Kementerian Perdagangan mencatat saat ini terdapat lebih dari 600 (enam ratus) waralaba/franchise di seluruh Indonesia. Dari jumlah tersebut, 400 waralaba diantaranya merupakan waralaba asing dan sisanya merupakan waralaba lokal. Jumlah gerai mencapai 24.400 (dua puluh empat ribu empat ratus) outlet dengan total pendapatan sebesar 172 (seratus tujuh puluh dua) Triliun Rupiah pada tahun 2015. Namun jumlah waralaba yang Sudah Memiliki Surat Tanda Pendaftaran 
Zil Aidi dan Hasna Farida: Perlindungan Hukum Para Pihak Dalam Perjanjian Waralaba..

Waralaba (STPW) hanya 360 (tiga ratus enam puluh) waralaba dengan rincian 308 (tiga ratus delapan) waralaba asing dan 52 (lima puluh dua) waralaba dalam negeri (Artikel Tempo.com, 2019: 3/10).

Ditinjau dari perspektif regulasi, instrumen hukum mengenai waralaba di Indonesia saat ini yang berlaku adalah Peraturan Pemerintah Nomor 42 Tahun 2007 tentang Waralaba yang masih berlaku hingga saat ini. Terdapat juga instrumen pengaturan lain yakni Peraturan Menteri Perdagangan Republik Indonesia Nomor 12/M-Dag/Per/3/2006 tentang Ketentuan dan tata Cara Penerbitan Surat Tanda Pendaftaran Usaha Waralaba yang terakhir diubah dengan Peraturan Menteri Perdagangan Republik Indonesia Nomor 53/M-Dag/Per/8/2012.

Selain itu terkhusus mengenai waralaba makanan dan minuman juga diatur dalam Peraturan Menteri Perdagangan Nomor 58/MDag/Per/9/2014 tentang Perubahan atas Peraturan Menteri Perdagangan Nomor 07/M-Dag/Per/2013 tentang Pengembangan Kemitraan Dalam Waralaba Untuk Jenis Usaha Jasa Makanan Dan Minuman.

Kehadiran bisnis waralaba sebagai suatu sistem bisnis mempunyai karakteristik tersendiri dalam kehidupan ekonomi, dapat juga menimbulkan permasalahan di bidang hukum dikarenakan bisnis waralaba didasarkan pada suatu perjanjian yang menimbulkan hak dan kewajiban (Asuan, 2017: 262). Terlebih saat ini jangkauan bisnis waralaba telah merambah ke berbagai bidang seperti perhotelan, kesehatan, laundry, jasa pendidikan, dan juga kuliner. Perkembangan bisnis ini sudah seyogyanya diiringi dengan perlindungan hukum yang memadai agar tidak ada pihak yang dirugikan.

Bentuk kesepakatan para pihak dalam waralaba umumnya dituangkan kedalam sebuah perjanjian waralaba yang memuat hak dan kewajiban para pihak. Perjanjian waralaba atau di dalam bahasa Inggris disebut franchise agreement ini adalah pemberian hak oleh franchisor (pemberi waralaba) kepada franchisee (penerima waralaba) untuk menggunakan kekhasan usaha berupa jenis produk dan bentuk yang diusahakan termasuk identitas perusahaan (logo, merek dan desain perusahaan, penggunaan rencana pemasaran serta pemberian bantuan yang luas, waktu atau jam operasional, pakaian dan penampilan karyawan). Oleh karena itu kekhasan usaha atau ciri-ciri pengenal bisnis dagang atau jasa milik franchisee sama dengan kekhasan usaha atau bisnis dagang atau jasa milik franchisor.

Sebagaimana dalam perjanjian pada umumnya, perjanjian waralaba (franchise agreement), tunduk pada buku III KUHPerdata sebagai pengaturan secara umum dan Peraturan Pemerintah Nomor 42 Tahun 2007 sebagai pengaturan secara khusus. Perjanjian waralaba memuat kumpulan persyaratan, ketentuan dan komitmen yang dibuat dan dikehendaki oleh para pihak. Penerima waralaba atau franchisee adalah pihak baik itu individu perorangan atau badan usaha baik yang berbadan hukum atau tidak yang 
diberikan hak oleh pemberi waralaba untuk memanfaatkan waralaba yang dimiliki oleh pemberi waralaba. Sebaliknya, pemberi waralaba atau biasa disebut juga franchisor adalah individu perorangan atau badan usaha baik yang berbadan hukum atau tidak yang memberikan hak untuk memanfaatkan waralaba yang dimilikinya kepada pihak penerima waralaba. Dua pihak ini lah yang terdapat dalam setiap perjanjian waralaba.

Adapun ketentuan-ketentuan yang umumnya diatur dalam suatu perjanjian waralaba yakni terkait dengan hak dan kewajiban para pihak, biaya-biaya yang harus ditanggung dan juga terkait jangka waktu perjanjian waralaba tersebut.

Bakso Tengkleng Mas Bambang merupakan salah satu usaha di bidang kuliner yang melakukan waralaba dalam pengembangan bisnisnya. Usaha kuliner yang berpusat di Klaten ini menyediakan berbagai macam makanan dan minuman dengan bakso tengkleng sebagai menu andalan. Bakso Tengkleng Mas Bambang telah memiliki jangkauan waralaba yang cukup luas Jawa dengan merambah sejumlah kota besar antara lain Yogyakarta, Solo, Semarang, Cirebon, Malang, Tangerang, Bandung dan berbagai kota lainnya di Indonesia.

Setiap pemberi waralaba pada umumnya termasuk Bakso Tengkleng Mas Bambang memiliki perjanjian standar yang akan ditawarkan kepada calon penerima waralaba untuk disepakati, dimana bentuk dan isi perjanjian tersebut sudah ditentukan oleh pemberi waralaba. Adapun perjanjian waralaba pada Bakso Tengkleng Mas Bambang dinamai dengan Perjanjian Kerjasama Bakso Tengkleng Mas Bambang.

Berdasarkan data yang diperoleh dari Bakso Tengkleng Mas Bambang selaku franchisor ditemukan fakta bahwa kerap terjadi wanprestasi yang dilakukan oleh mitra usaha atau franchisee terhadap perjanjian waralaba.

Perlindungan hukum sangat penting untuk mengetahui dan memberikan kepastian bahwa seseorang akan mendapatkan apa yang menjadi hak dan kewajibannya. Dengan adanya perlindungan hukum yang memadai, akan tercipta rasa aman dan percaya bagi para pihak dalam perjanjian waralaba serta diharapkan bisnis waralaba akan berkembang lebih pesat dan dapat terus berkontribusi bagi sektor ekonomi domestik Indonesia.

Berdasarkan latar belakang di atas menarik untuk diteliti dan dikaji mengenai, bagaimana bentuk perlindungan hukum terhadap para pihak dalam Perjanjian Waralaba Bakso Tengkleng Mas Bambang dan bagaimana upaya yang dapat ditempuh para pihak dalam hal terjadi wanprestasi dalam pelaksanaan Perjanjian Waralaba tersebut?

\section{METODE PENELITIAN}

Sebuah studi logis dan sistematis mengenai prinsip-prinsip yang mengarahkan jalannya penelitian ilmiah 
Zil Aidi dan Hasna Farida: Perlindungan Hukum Para Pihak Dalam Perjanjian Waralaba..

adalah definisi dari metodologi (Sumardjono, 2001: 8).

Penelitian pada hakikatnya adalah suatu kegiatan yang mencari kebenaran dari suatu ilmu pengetahuan, dimana penelitian itu lahir dari adanya keraguan atau keingintahuan terhadap suatu masalah (Asikin, 2004: 34).

Dalam tulisan ini penelitian yang dilakukan merupakan penelitian yuridis empiris. Pendekatan yuridis empiris adalah pendekatan yang melihat suatu kenyataan hukum di dalam masyarakat yang bagaimana bentuk perlindungan hukum terhadap para pihak dalam Perjanjian Waralaba Bakso Tengkleng Mas Bambang dan juga untuk mengetahui upaya yang dapat ditempuh para pihak dalam hal terjadi wanprestasi dalam pelaksanaan Perjanjian Waralaba tersebut.

Selanjutnya, untuk mengetahui hal ini maka akan digunakan analisis data yang bersifat kualitatif. Data kualitatif dalam hal ini berupa kata-kata, sehingga laporan penelitian akan berisi kutipan-kutipan data untuk memberi gambaran penyajian yang berasal dari wawancara dan beberapa catatan lapangan.

\section{HASIL DAN PEMBAHASAN}

\section{Perlindungan Hukum Terhadap Para Pihak Dalam Perjanjian Waralaba Bakso Tengkleng Mas Bambang}

Ekspansi bisnis dengan sistem waralaba/franchise sedang berkembang pesat di Indonesia (Artikel okezone.com, 2019 : 3/7). Sebagaimana yang juga telah disampaikan sebelumnya, berdasarkan
Pasal 1 angka 1 Peraturan Pemerintah Nomor 42 Tahun 2007 tentang Waralaba dijelaskan bahwa waralaba merupakan hak khusus yang dipunyai oleh individu perorangan atau badan usaha baik yang berbadan hukum atau tidak terhadap sistem bisnis yang di dalamnya terdapat ciri khas dalam rangka memasarkan barang atau jasa yang telah terbukti berhasil dan dapat dimanfaatkan oleh pihak lain di dalam suatu kerangka perjanjian. Mengenai para pihak yang melaksanakan waralaba, berdasarkan Pasal 1 angka 2 dan 3 Peraturan Pemerintah Nomor 42 Tahun 2007 tentang waralaba dikatakan bahwa orang perorangan atau badan yang memberikan hak untuk memanfaatkan dan/atau menggunakan waralaba yang dimilikinya disebut dengan pemberi waralaba atau franchisor, sedangkan orang perseorangan atau badan yang diberikan hak untuk memanfaatkan dan/atau menggunakan waralaba disebut penerima waralaba atau franchisee.

Bisnis waralaba menjadi populer dan berkembang pesat di Indonesia karena bentuk ini menguntungkan kedua belah pihak yakni pemberi waralaba dan penerima waralaba. Bagi penerima waralaba keuntungan yang diperoleh yakni penerima waralaba tidak usah memulai bisnisnya dari nol karena bisnis pemberi waralaba (franchisor) sudah terkenal dan mempunyai pasar, sehingga penerima waralaba (franchisee) mempunyai peluang untuk berkembang cepat. Keuntungan menjalankan bisnis waralaba bagi pemberi waralaba adalah 
bisnisnya bisa berkembang lebih cepat di banyak lokasi secara bersamaan dan meningkatnya keuntungan dengan memanfaatkan investasi dari penerima waralaba (Astuti, 2005: 91).

Bakso Tengkleng Mas Bambang sebagai usaha yang menggunakan waralaba dalam pengembangan bisnisnya, wajib memenuhi 6 (enam) kriteria sebagaimana dalam Pasal 3 Peraturan Pemerintah Nomor 42 Tahun 2007 tentang Waralaba. Berdasarkan hasil penelitian, waralaba ini telah memenuhi seluruh kriteria tersebut dan dapat dikatakan sebagai rumah makan yang menjalankan bisnisnya dengan sistem waralaba. Kriteria yang dimaksud yakni:

a. Memiliki ciri khas usaha

Waralaba harus memiliki suatu keunggulan atau perbedaan yang tidak mudah ditiru dibandingkan dengan usaha lain sejenis, dan membuat konsumen selalu mencari ciri khas yang dimaksud. Ciri khas usaha yang dimiliki oleh Bakso Tengkleng Mas Bambang berupa makanan yang ditawarkan. Berbagai makanan yang ditawarkan antara lain bakso tengkleng, bakso pop nugget keju, mie ayam pangsit, siomay tenggiri, dan sebagainya. Bakso yang dihasilkan juga terasa dagingnya karena dibuat dari 97\% (sembilan puluh tujuh persen) daging dan $3 \%$ (tiga persen) tepung

b. Terbukti sudah memberikan keuntungan
Pengalaman selama minimal 9 tahun serta memahami kiat dan cara mengatasi permasalahan dalam bisnis adalah syarat yang harus dipenuhi jika seseorang ingin menjadi pemberi waralaba atau franchisor. Sampai saat ini usaha milik pemberi waralaba terbukti masih bertahan, menguntungkan dan usahanya terus berkembang. Usaha makanan ini telah berdiri sejak tahun 2009 dan sudah 9 (sembilan) tahun melakukan usaha waralaba. Dalam kurun waktu tersebut, keuntungan dan manfaat yang diberikan kepada penerima waralaba yakni:

1) Memberikan keuntungan dalam bidang pemasaran dan penguasaan pasar karena Bakso Tengkleng Mas Bambang merupakan merek yang dikenal di masyarakat dan saat ini sudah terdapat 26 (dua puluh enam) cabang rumah makan.

2) Memberikan keuntungan secara materiil karena dengan membuka usaha waralaba ini, maka penerima waralaba akan menerima pendapatan yang diperoleh setiap bulannya.

3) Tidak terdapat royalty fee, sehingga keuntungan penjualan yang dihasilkan akan diterima bersih oleh penerima waralaba.

c. Memiliki standar atas pelayanan dan barang dan/atau jasa yang ditawarkan Pengaturan mengenai standarisasi bahan baku, cara pengolahan, manajemen rumah 
Zil Aidi dan Hasna Farida: Perlindungan Hukum Para Pihak Dalam Perjanjian Waralaba..

makan tertuang dalam standar operasional tertulis yang dibuat oleh manajemen pemberi waralaba wajib ditaati oleh seluruh penerima waralaba.

d. Mudah diajarkan dan diaplikasikan

Pemberi waralaba hendaknya memiliki usaha yang mudah dan praktis untuk dijalankan, sehingga waralaba yang ditawarkan bisa dijalankan oleh semua pihak baik yang sudah berpengalaman mengenai usaha sejenis maupun yang belum berpengalaman, selanjutnya pemberi waralaba juga wajib menyediakan bimbingan baik dari segi manajemen maupun operasional yang berkelanjutan kepada penerima waralaba. Usaha Bakso Tengkleng Mas Bambang merupakan usaha yang mudah diajarkan dan diaplikasikan. Sebelum gerai rumah makan dibuka, para karyawan akan terlebih dahulu diberi pelatihan selama 1 (satu) minggu. Setelah rumah makan dibuka maka pemberi waralaba akan tetap melakukan pengawasan dan pembinaan selama 1 (satu) bulan sekali. Cara pengolahan juga tergolong mudah dan praktis. Semua bahan baku mulai dari bakso, mie, kaldu, dan bumbu sudah jadi sehingga praktis untuk dibuat. Penerima waralaba membeli produk yang telah disediakan oleh pemberi waralaba kemudian diolah dan disajikan sesuai dengan resep yang ditetapkan oleh Bakso Tengkleng Mas Bambang. e. Adanya dukungan yang berkesinambungan

Dukungan yang berkesinambungan dapat dilihat dari kegiatan saling mendukung antara penerima waralaba dan pemberi waralaba untuk memajukan dan melaksanakan kegiatan waralaba. Selain itu, dalam perjanjian waralaba antara Bakso Tengkleng Mas Bambang dan mitra/penerima waralaba juga disebutkan bahwa pemberi waralaba berkewajiban menyelenggarakan pelatihan bagi penerima waralaba secara berkelanjutan setidaknya 2 kali dalam satu tahun.

f. Hak Kekayaan Intelektual yang telah terdaftar

Hak Kekayaan Intelektual sangat erat kaitannya dengan waralaba seperti hak cipta, paten dan rahasia dagang. Pihak pemberi waralaba telah mendaftarkan merek dagang "Bakso Tengkleng Mas Bambang" pada Direktorat Jenderal HKI pada tanggal 29 Oktober 2010 dengan nomor pendaftaran C00201003847.

Lebih lanjut, Pasal 1 angka 1 Peraturan Pemerintah Nomor 42 Tahun 2007 tentang Waralaba menyatakan bahwa waralaba harus didahului dengan adanya perjanjian. Apabila salah satu pihak melanggar perjanjian, maka pihak lain dapat menuntut pihak yang melanggar tersebut sesuai dengan hukum yang berlaku. 
Perjanjian waralaba merupakan bentuk perjanjian yang isinya memberikan hak dan kewenangan khusus kepada pihak penerima waralaba, untuk melakukan penjualan atas produk berupa barang dan/atau jasa dengan mempergunakan nama dagang atau merek dagang tertentu dan melakukan kegiatan usaha berdasarkan suatu format bisnis yang telah ditentukan oleh pemberi waralaba (Harnoko, 2015: 14). Perjanjian waralaba memuat hal-hal sebagai berikut (Sutedi, 2008: 82):

a. Hak yang meliputi penggunaan metode atau resep yang khusus, penggunaan merek, nama dagang, jangka waktu, perpanjangan serta wilayah kegiatan dan hak yang lain yang diberikan oleh pemberi waralaba kepada penerima waralaba;

b. Imbalan yang diberikan oleh penerima waralaba atas hak-hak yang diterima dari pemberi waralaba pada saat usaha mulai dijalankan;

c. Pengaturan yang wajib disepakati sebelumnya adalah terkait penjualan hak penerima waralaba kepada pihak lain. Dalam kondisi penerima waralaba tidak ingin meneruskan usaha waralaba dan berencana menjualnya kepada pihak lain;

d. Ketentuan terkait pengakhiran kerjasama waralaba.

Perjanjian waralaba merupakan salah satu aspek penting dalam waralaba, karena di sanalah perlindungan hukum bagi para pihak akan diatur. Perlindungan hukum bagi para pihak menjadi penting guna melindungi mereka dari perbuatan merugikan pihak lain dan memberikan perlindungan hukum terhadap Hak Kekayaan Intelektual. Perjanjian waralaba memberikan kepastian bahwa seseorang akan mendapatkan hak dan kewajibannya, sehingga yang para pihak merasa aman.

Lebih jauh berbicara mengenai perlindungan hukum, perlindungan hukum yang dapat dilakukan kepada para pihak yakni subjek pelaku penerima waralaba (franchisee) dan pemberi waralaba (franchisor) yakni perlindungan hukum preventif dan represif. Perlindungan Hukum preventif bertujuan untuk mencegah terjadinya suatu sengketa yang dilakukan kedua belah pihak pelaku bisnis waralaba serta memberikan ramburambu atau batasan dalam melaksanakan kewajiban dalam waralaba. Sedangkan perlindungan hukum represif menitikberatkan pada mekanisme penyelesaian sengketa apabila terjadi permasalahan di kemudian hari (Sari, 2016: 3). Perlindungan hukum ini adalah perlindungan hukum akhir dimana perlindungan yang diberikan berupa sanksi seperti denda, penjara, dan hukuman tambahan yang diberikan apabila sudah menjadi sengketa atau telah dilakukan suatu pelanggaran.

Perlindungan hukum secara preventif telah diakomodir pada oleh perjanjian waralaba Bakso Tengkleng Mas Bambang yakni dengan adanya pengaturan mengenai kewajiban dari para pihak pada Pasal 5 dan Pasal 6. Pasal 5 Perjanjian Waralaba Bakso Tengkleng Mas Bambang mengatur mengenai kewajiban 
Zil Aidi dan Hasna Farida: Perlindungan Hukum Para Pihak Dalam Perjanjian Waralaba..

pemberi waralaba. Kewajiban pemberi waralaba yakni:

a. Memberikan panduan operasional tata kelola Bakso Tengkleng Mas Bambang kepada Penerima waralaba;

b. Menyediakan program pelatihan/pembinaan tata kelola operasional kepada pegawai dan crew Penerima waralaba;

c. Menyediakan alternatif desain interior atas biaya dari Penerima waralaba sendiri;

d. Menyelenggarakan program pelatihan untuk Penerima waralaba secara berkesinambungan dan berkala paling sedikit 2 kali dalam setahun;

e. Memberikan konsultasi gratis kepada Penerima waralaba apabila gerai Penerima waralaba berada dalam keadaan kritis yang dapat menyebabkan tutupnya atau berhentinya bisnis Bakso Tengkleng Mas Bambang milik Penerima waralaba;

f. Menyediakan bahan baku guna memasok bahan baku untuk operasional di setiap gerai Bakso Tengkleng Mas Bambang;

g. Melakukan program pemasaran secara nasional.

Pada Pasal 6 Perjanjian Waralaba Bakso Tengkleng Mas Bambang mengatur mengenai kewajiban penerima waralaba. Kewajiban penerima waralaba yakni:

a. Seluruh biaya untuk pengadaan perabotan untuk keperluan gerai serta bahan bahan baku pembuat menu Bakso Tengkleng Mas Bambang yang sesuai standar Pemberi waralaba serta biaya-biaya lain seperti pengurusan perizinan atas pembukaan dan pengoperasian restoran menjadi tanggungan Penerima waralaba sendiri;

b. Penerima waralaba setuju bahwa pengadaan brosur, kartu nama, formulir, kwitansi, seragam, bahan/alat promosi dan benda-benda lain yang diperlukan untuk menunjang usaha Bakso Tengkleng Mas Bambang;

c. Penerima waralaba atau pekerja yang dipekerjakan oleh Penerima waralaba pada gerai wajib mengikuti program pelatihan dan kerja praktek yang diselenggarakan Pemberi waralaba atas biaya Penerima waralaba;

d. Menjaga kerahasiaan manajemen, sistem usaha termasuk buku panduan operasional usaha, cara-cara pengelolaan, jenis dan sumber bahan baku dari Pemberi waralaba

e. Menjaga dan merawat merek dari sistem usaha franchise Rumah Makan Bakso Tengkleng Mas Bambang selama masa perjanjian;

f. Menaati prosedur operasional usaha dan tata tertib franchise Rumah Makan Bakso Tengkleng Mas Bambang;

g. Untuk taat pada peraturan pemerintah yang berlaku.

Adapun tujuan dari pencantuman pasal-pasal tersebut adalah untuk menciptakan suatu kesepahaman antar para pihak terhadap hak dan kewajiban masing-masing pihak dalam perjanjian 
tersebut. Hal ini diharapkan dapat meminimalisir terjadinya pelanggaranpelanggaran terhadap isi perjanjian atau adanya wanprestasi yang didasari oleh ketidaktahuan atau ketidaksepahaman antara para pihak atas kewajiban masingmasing.

Perlindungan hukum secara preventif juga tercantum dalam Pasal 6 ayat (4), Pasal 6 ayat (5), Pasal 6 ayat (6), Pasal 1 angka 9 dan Pasal 11 Perjanjian Waralaba Bakso Tengkleng Mas Bambang. Pasal 6 ayat (4) menyatakan bahwa penerima waralaba wajib menjaga kerahasiaan manajemen, sistem usaha termasuk buku panduan operasional usaha, cara-cara pengelolaan, jenis dan sumber bahan baku dari pemberi waralaba. Selanjutnya, Pasal 6 ayat (5) menyatakan bahwa penerima waralaba wajib menjaga dan merawat merek dari sistem usaha franchise Rumah Makan Bakso Tengkleng Mas Bambang selama masa perjanjian. Pasal 6 ayat (6) menyatakan bahwa penerima waralaba wajib menaati prosedur operasional usaha dan tata tertib franchise Rumah Makan Bakso Tengkleng Mas Bambang. Pasal 1 angka 9 menyebutkan bahwa pihak penerima waralaba tidak akan menyediakan minuman dalam kemasan dan menyajikan makanan lain dan usaha lain selain Bakso Tengkleng Mas Bambang. Pasal 11 menyatakan bahwa pihak penerima waralaba diwajibkan untuk merahasiakan sistem, manajemen dan cara-cara pengelolaan rumah makan yang didapat dari pihak pemberi waralaba. Pengaturan ini penting untuk mencegah adanya wanprestasi dan melindungi rahasia dagang pemberi waralaba.

Perlindungan hukum represif juga telah cukup terfasilitasi dalam Pasal 13 perjanjian waralaba Bakso Tengkleng Mas Bambang tentang pernyelesaian sengketa. Pasal 13 pada pokoknya menyatakan bahwa apabila timbul sengketa diantara kedua belah pihak akibat perjanjian ini akan diselesaikan secara musyawarah dan mufakat. Apabila dalam musyawarah untuk mufakat tersebut tidak berhasil menapai kesepakatan maka kedua belah pihak akan menyelesaikan secara hukum dan karenanya kedua belah pihak memilih domisili hukum yang tetap di kantor kepaniteraan Pengadilan Negeri sebagai mana disepakati oleh kedua belah pihak.

Meskipun klausula-klausula pada perjanjian waralaba Bakso Tengkleng Mas Bambang telah meliputi perlindungan hukum secara represif dan juga preventif akan tetapi menurut hemat penulis belumlah dapat secara optimal melindungi para pihak. Salah satu hal yang dirasa kurang melindungi para pihak yakni terkait klausula minimum yang harus dimuat dalam suatu perjanjian waralaba.

Sekalipun suatu perjanjian dibuat berdasarkan asas kebebasan berkontrak atau asas pacta sunt servanda dimana setiap orang bebas untuk menentukan isi perjanjian yang dibuat, namun untuk perjanjian waralaba telah ditentukan kerangka perjanjiannya secara imperatif dalam Peraturan Pemerintah Nomor 42 Tahun 2007 tentang Waralaba dan 
Zil Aidi dan Hasna Farida: Perlindungan Hukum Para Pihak Dalam Perjanjian Waralaba..

Lampiran II Peraturan Menteri Perdagangan Republik Indonesia Nomor 53/M-DAG/PER/8/2012 tentang

Penyelenggaraan Waralaba.

Pengaturan mengenai klausula minimal dalam sebuah perjanjian waralaba dimaksudkan untuk memberikan upaya perlindungan hukum terhadap kedua pihak khususnya penerima waralaba yang pada umumnya memiliki kedudukan atau posisi yang lemah dibanding pemberi waralaba. Dengan adanya pengaturan mengenai klausula minimal dalam sebuah perjanjian waralaba diharapkan tidak ada pihak yang dirugikan atau terpaksa.

Berdasarkan Pasal 5 Peraturan Pemerintah Nomor 42 Tahun 2007 tentang Waralaba, perjanjian waralaba memuat klausula paling sedikit:

a. Nama dan alamat para pihak;

b. Jenis dan Hak Kekayaan Intelektual;

c. Kegiatan usaha;

d. Hak dan kewajiban para pihak;

e. Bantuan, fasilitas, bimbingan operasional, pelatihan, dan pemasaran yang diberikan Pemberi waralaba kepada Penerima waralaba;

f. Wilayah usaha;

g. Jangka waktu perjanjian;

h. Tata cara pembayaran imbalan;

i. Kepemilikan, perubahan kepemilikan, dan hak ahli waris;

j. Penyelesaian sengketa; dan

k. Tata cara perpanjangan, pengakhiran dan pemutusan perjanjian.

Di samping itu, pengaturan mengenai klausula minimum yang harus dimuat dalam suatu perjanjian waralaba juga diatur dalam Lampiran II Peraturan Menteri Perdagangan Republik Indonesia Nomor 53/M-DAG/PER/8/2012 tentang Penyelenggaraan Waralaba. Akan tetapi, terdapat perbedaan antara Peraturan Pemerintah Nomor 42 Tahun 2007 tentang Waralaba dan Lampiran II Peraturan Menteri Perdagangan Republik Indonesia Nomor 53/MDAG/PER/8/2012 tentang Penyelenggaraan Waralaba. Pada Lampiran II Peraturan Menteri Perdagangan Republik Indonesia Nomor 53/M-DAG/PER/8/2012 tentang Penyelenggaraan Waralaba memuat 2 (dua) klausul tambahan mengenai klausula yang harus dimuat dalam perjanjian waralaba, dimana hal tersebut tidak diatur dalam Peraturan Pemerintah Nomor 42 Tahun 2007 tentang Waralaba.

Klausula tersebut yakni adanya klausul mengenai jaminan dari pihak pemberi waralaba untuk tetap menjalankan kewajiban-kewajibannya kepada penerima waralaba sesuai dengan isi perjanjian hingga jangka waktu perjanjian berakhir dan mengenai Jumlah gerai yang akan dikelola oleh penerima waralaba. Peraturan Pemerintah Nomor 42 Tahun 2007 tentang Waralaba mengharuskan adanya klausul mengenai kepemilikan, perubahan kepemilikan, dan hak ahli waris, dimana hal tersebut tidak termasuk klausula minimum yang harus dimuat dalam suatu perjanjian waralaba dalam Lampiran II Peraturan Menteri Perdagangan Republik Indonesia Nomor 53/M-DAG/PER/8/2012 tentang Penyelenggaraan Waralaba. 
Dalam perspektif yang berbeda, adanya ketidaksamaan klausula minimum pada kedua instrument hukum ini tentunya dapat menimbulkan ketidakpastian hukum bagi para pihak dalam perjanjian waralaba. Tentu dibutuhkan tindak lanjut dari pihak terkait dalam hal ini pemerintah untuk mengharmonisasikan substansi dari setiap instrumen hukum yang mengatur hal yang sama.

Berdasarkan hasil penelitian, perjanjian waralaba Bakso Tengkleng Mas Bambang hanya memenuhi 10 (sembilan) klausula dari 13 (tiga belas) klausula yang harus dimuat oleh suatu perjanjian waralaba yakni:

a. Nama dan alamat para pihak

Dalam perjanjian waralaba sudah terdapat nama dan alamat para pihak. Hal ini tercantum dalam komparisi perjanjian yang memuat identitas para pihak yang memuat nama, alamat, NIK, tempat tanggal lahir, dan nomor telepon.

b. Jenis dan Hak Kekayaan Intelektual

Meskipun tidak tertuang dalam pasal tersendiri, namun jenis dan Hak Kekayaan Intelektual tercantum dalam premise perjanjian yakni Pemberi waralaba memberikan izin kepada Penerima waralaba dengan nama Rumah Makan Bakso Tengkleng Mas Bambang untuk itu Penerima waralaba dapat menggunakan merek dan sistem secara bersamaan dengan Penerima waralaba lainnya yang sudah diizinkan oleh Pemberi waralaba sebelumnya. Namun dalam perjanjian tidak disebutkan nomor dan kapan didaftarkan.

c. Kegiatan usaha

Mengenai kegiatan usaha, telah dijelaskan dalam premise perjanjian waralaba bahwa bisnis Pemberi waralaba adalah rumah makan yang menyajikan makanan siap saji yang dikenal dengan nama Bakso Tengkleng Mas Bambang.

d. Hak dan kewajiban para pihak

Kewajiban para pihak diatur dalam Pasal 5 dan Pasal 6 perjanjian waralaba. Akan tetapi hak para pihak tidak diatur secara jelas dalam pasal tersendiri dalam perjanjian waralaba Bakso Tengkleng Mas Bambang.

e. Bantuan, fasilitas, bimbingan operasional, pelatihan, dan pemasaran yang diberikan Pemberi waralaba kepada Penerima waralaba.

Hal ini terdapat dalam Pasal 5 ayat (2) perjanjian waralaba Bakso Tengkleng Mas Bambang, Pemberi waralaba berkewajiban untuk menyediakan program pelatihan/ pembinaan tata kelola operasional kepada pegawai dan crew Penerima waralaba. Pemberi waralaba juga berkewajiban melakukan program pemasaran secara nasional.

f. Wilayah usaha

$$
\begin{aligned}
& \text { Klausula mengenai wilayah } \\
& \text { usaha terdapat dalam premise } \\
& \text { perjanjian yang menyebutkan bahwa }
\end{aligned}
$$


Zil Aidi dan Hasna Farida: Perlindungan Hukum Para Pihak Dalam Perjanjian Waralaba..

Pemberi waralaba setuju untuk memberikan izin dan membantu Penerima waralaba menjual dan menyajikan makanan Bakso Tengkleng Mas Bambang untuk wilayah yang di tempati oleh penerima waralaba.

g. Jangka waktu perjanjian

Mengenai jangka waktu perjanjian terdapat dalam Pasal 10 perjanjian waralaba yakni 5 (lima) tahun.

h. Tata cara pembayaran imbalan.

Mengenai tata cara pembayaran imbalan, pasal 7 perjanjian waralaba menyatakan bahwa Penerima waralaba setuju membayar kepada Pemberi waralaba semua biaya dan iuran sesuai dengan perjanjian ini termasuk biaya atau tagihan tambahan atas semua produk atau jasa-jasa yang diberikan atau akan diberikan kepada Pemberi waralaba.

Dalam Pasal 1 angka (8) Penerima waralaba menyatakan untuk memenuhi seluruh persyaratan yang ditetapkan oleh Pemberi waralaba yaitu Penerima waralaba menyediakan modal awal usaha sebesar sesuai dengan paket kemitraan yang dipilih dan ditransfer ke rekening Pemberi waralaba.

i. Penyelesaian sengketa

Mekanisme penyelesaian sengketa terdapat dalam pasal 13 mengenai penyelesaian perselisihan. j. Tata cara perpanjangan, pengakhiran dan pemutusan perjanjian

Tata cara perpanjangan termuat dalam Pasal 10 perjanjian waralaba dimana atas kesepakatan kedua belah pihak perjanjian dapat diperpanjang dengan syarat pembayaran $60 \%$ (enam puluh persen) ditambah satu boots. Maksud penambahan satu boots ini adalah penambahan satu gerobak untuk jenis makanan yang baru, sebagai contoh apabila penerima waralaba belum memiliki gerobak siomay maka cabang tersebut Bambang tersebut diwajibkan untuk menambah satu gerobak siomay. Aturan mengenai pembatalan perjanjian terdapat dalam Pasal 12 perjanjian waralaba.

Klausula mengenai kepemilikan, perubahan kepemilikan, dan hak ahli waris, tidak terdapat dalam perjanjian waralaba Bakso Tengkleng Mas Bambang sebagaimana dipersyaratkan oleh Pasal 5 Peraturan Pemerintah Nomor 42 Tahun 2007 tentang Waralaba. Perjanjian waralaba juga tidak mengatur mengenai klausula adanya jaminan dari pihak Pemberi waralaba untuk tetap menjalankan kewajiban-kewajibannya kepada Penerima waralaba sesuai dengan isi perjanjian hingga jangka waktu perjanjian berakhir dan ketentuan mengenai jumlah gerai yang akan dikelola oleh penerima waralaba sebagaimana dalam Lampiran II Peraturan Menteri Perdagangan Republik Indonesia Nomor 53/M-DAG/PER/8/2012 tentang Penyelenggaraan Waralaba dalam 
perjanjian waralaba Bakso Tengkleng Mas Bambang.

Tidak ada sanksi yang diterapkan ketika klausula minimal suatu perjanjian waralaba tidak terpenuhi sebagaimana dalam Pasal 5 Peraturan Pemerintah Nomor 42 Tahun 2007 tentang Waralaba dan Lampiran II Peraturan Menteri Perdagangan Republik Indonesia Nomor 53/M-DAG/PER/8/2012 tentang Penyelenggaraan Waralaba. Meskipun demikian, dengan tidak terpenuhinya klausula minimum sebagaimana telah ditetapkan mengakibatkan kurangnya perlindungan hukum bagi penerima waralaba. Penerima waralaba menjadi tidak terlindungi apabila dalam pelaksanaan perjanjian terjadi perubahan kepemilikan dan penerima waralaba ingin memberikan usaha tersebut pada ahli waris. Penerima waralaba juga tidak mendapat jaminan dari pihak Pemberi waralaba untuk tetap menjalankan kewajiban-kewajibannya kepada Penerima waralaba sesuai dengan isi perjanjian hingga jangka waktu perjanjian berakhir.

Kurangnya perlindungan hukum juga terlihat pada klausula mengenai pembatalan perjanjian. Berdasarkan Pasal 12 ayat (1) dan ayat (2) Perjanjian Waralaba Bakso Tengkleng Mas Bambang tentang Pembatalan menyebutkan bahwa pemberi waralaba dapat membatalkan secara sepihak perjanjian karena penerima waralaba lalai atau tidak melakukan kewajiban padahal telah diberi peringatan ketiga oleh Pemberi waralaba namun masih melakukan pelanggaran baik yang berbeda maupun sama, dimana pelanggaran tersebut dianggap serius sebagaimana tertulis dalam surat peringatan/teguran yang menurut ukuran pemberi waralaba dan apabila penerima waralaba dinyatakan pailit. Pembatalan perjanjian secara sepihak tersebut merugikan penerima waralaba dan menjadikan posisi penerima waralaba menjadi lemah.

Perjanjian waralaba digolongkan sebagai perjanjian standar, sehingga isi dari perjanjian tersebut telah terstandarisasi isinya oleh pihak yang secara kedudukan ekonomi lebih kuat, sedangkan pihak lain yang secara ekonomi memiliki posisi tawar lebih rendah hanya dapat memutuskan apakah akan menerima atau menolak perjanjian tersebut tanpa memiliki kesempatan untuk melakukan perubahan terhadap isi dari perjanjian. Apabila menolak maka tentunya perjanjian itu dianggap tidak pernah ada karena debitur tidak menandatangani perjanjian tersebut (Salim, 2007: 147). Akibat perjanjian waralaba sering dibuat oleh pemberi waralaba (franchisor) maka terdapat ketimpangan dalam hubungan hukum (unequal bargaining power) antara pemberi waralaba (franchisor) dan penerima waralaba (franchisee) (Lasamahu, 2006: 308). Perjanjian seperti ini sering kali memberatkan penerima waralaba karena didominasi kepentingan pemberi waralaba.

Salah satu alasan pembatalan perjanjian secara sepihak yakni karena 
Zil Aidi dan Hasna Farida: Perlindungan Hukum Para Pihak Dalam Perjanjian Waralaba..

penerima waralaba lalai atau tidak melakukan kewajiban padahal telah diberi peringatan ketiga oleh pemberi waralaba namun masih melakukan pelanggaran baik itu yang tergolong pelanggaran yang sama dengan sebelumnya atau yang berbeda dimana pelanggaran tersebut dianggap serius sebagaimana tertulis dalam surat peringatan/teguran yang diteribitkan oleh pemberi waralaba. Kata "menurut ukuran pemberi waralaba" menimbulkan ketidakpastian terhadap penerima waralaba. Perjanjian Waralaba Bakso Tengkleng Mas Bambang juga tidak mencantumkan pasal mengenai wanprestasi maupun force majeure. Tidak adanya pengaturan tersebut dan hanya berdasarkan ukuran pemberi waralaba, mengakibatkan penerima waralaba tidak mengetahui hal apa saja yang mengakibatkan terjadinya wanprestasi dan apabila dalam pelaksanaan terdapat force majeure.

Menurut Abdulkadir Muhammad, ada tiga hal yang harus diperhatikan sebagai syarat supaya pembatalan itu dapat dilakukan. Tiga syarat itu adalah (Muhammad, 1982: 130):

a. Perjanjian harus bersifat timbal balik

b. Harus ada wanprestasi

c. Harus dengan putusan hakim

Dalam hal pembatalan tidak terjadi dengan sendirinya, melainkan harus melalui putusan pengadilan, yakni dengan mengajukan gugatan pembatalan. Dengan demikian yang membatalkan perjanjian itu bukanlah wanprestasi melainkan putusan hakim. Wanprestasi hanya sebagai syarat terbitnya putusan hakim
(Muhammad, 1982: 130). Seharusnya pembatalan sebuah perjanjian tidak dibatalkan secara sepihak melainkan atas kesepakatan kedua belah pihak atau melalui pengadilan.

Lebih lanjut, salah satu kewajiban penerima waralaba berdasarkan Pasal 6 Perjanjian Waralaba Bakso Tengkleng Mas Bambang yakni untuk taat pada peraturan pemerintah yang berlaku. Saat ini peraturan pemerintah yang terkait dengan waralaba yakni Peraturan Pemerintah Nomor 42 Tahun 2007 tentang Waralaba. Dalam Peraturan Pemerintah Nomor 42 Tahun 2007 tentang Waralaba, terdapat beberapa kewajiban yang harus dipenuhi oleh penerima waralaba maupun pemberi waralaba. Kewajiban tersebut antara lain kewajiban bagi pemberi waralaba untuk memberikan prospektus penawaran waralaba kepada calon penerima waralaba saat melakukan penawaran, kewajiban untuk mendaftarkan prospektus penawaran waralaba sebelum membuat perjanjian waralaba, dan kewajiban untuk mendaftarkan perjanjian waralaba bagi penerima waralaba.

Prospektus penawaran waralaba adalah keterangan tertulis dari pemberi waralaba yang paling sedikit menjelaskan tentang identitas, legalitas, sejarah kegiatan, struktur organisasi, keuangan, jumlah tempat usaha, daftar penerima waralaba, hak dan kewajiban pemberi dan penerima waralaba, sebagaimana diatur dalam Pasal 7 ayat (2) Peraturan Pemerintah Nomor 42 Tahun 2007 tentang Waralaba dan Lampiran I 
Peraturan Menteri Perdagangan Nomor 53/M-DAG/PER/8/2012 tentang

Penyelenggaraan Waralaba.

Bakso Tengkleng Mas Bambang sebagai salah satu usaha makanan dan minuman yang menyelenggarakan waralaba telah memiliki prospektus penawaran waralaba. Akan tetapi, dalam prospektus penawaran waralaba tersebut tidak terdapat syarat yang harus dimiliki oleh sebuah prospektus sebagaimana dalam Pasal 7 ayat (2) Peraturan Pemerintah Nomor 42 Tahun 2007 tentang Waralaba dan Lampiran I Peraturan Menteri Perdagangan Nomor 53/M-DAG/PER/8/2012 tentang Penyelenggaraan Waralaba. Prospektus yang dimiliki oleh Bakso Tengkleng Mas Bambang hanya berisi estimasi investasi dari nilai yang diberikan oleh mitra/penerima waralaba.

Berdasarkan Pasal 10 Peraturan Pemerintah Nomor 42 Tahun 2007 tentang Waralaba, pemberi waralaba juga wajib mendaftarkan prospektus penawaran waralaba sebelum membuat perjanjian Waralaba dengan Penerima waralaba. Pendaftaran prospektus penawaran waralaba bertujuan untuk mendapatkan Surat Tanda Pendaftaran Waralaba. Pemberi waralaba yang berasal dari dalam negeri wajib mendaftarkan prospektus penawaran waralaba ke Direktorat Bina Usaha Perdagangan up. Kantor Unit Pelayanan Perdagangan Kementerian Perdagangan dengan mengisi formulir surat permohonan Surat Tanda Pendaftaran Waralaba bagi pemberi waralaba dalam negeri.
Adapun pada saat penelitian ini dilakukan, prospektus penawaran waralaba Bakso Tengkleng Mas Bambang belum didaftarkan. Pendaftaran prospektus waralaba masih dalam proses pengurusan.

Berdasarkan Pasal 4 ayat (1) Peraturan Menteri Perdagangan Nomor 53/M-DAG/PER/8/2012 tentang Penyelenggaraan Waralaba pada saat pemberi waralaba melakukan penawaran kepada penerima waralaba, pemberi waralaba juga harus menyampaikan prospektus penawaran waralaba kepada penerima waralaba paling singkat 2 (dua) minggu sebelum penandatanganan perjanjian waralaba. Tujuan daripada penyampaian prospektus penawaran waralaba adalah agar penerima waralaba bisa melakukan studi kelayakan bisnis terhadap bisnis waralaba yang akan dijalaninya. Selain itu, agar penerima waralaba mengetahui apa yang menjadi keuntungan dan apa yang dapat dibebankan padanya (Kogin, 2014: 34).

Akan tetapi, dalam praktiknya prospektus penawaran yang dimiliki oleh Bakso Tengkleng Mas Bambang tidak disampaikan secara langsung pemilik dari Bakso Tengkleng Mas Bambang maupun dari manajemen kepada penerima waralaba. Proses penawaran waralaba hanya melalui diskusi antara penerima waralaba dengan pemberi waralaba dan melalui seminar.

Berkaitan dengan pendaftaran waralaba, tidak hanya pemberi waralaba yang harus mendaftarkan prospektus penawaran waralabanya, penerima 
Zil Aidi dan Hasna Farida: Perlindungan Hukum Para Pihak Dalam Perjanjian Waralaba..

waralaba juga harus melakukan pendaftaran perjanjian waralaba. Kewajiban ini tertuang dalam dalam Pasal 11 ayat (1) Peraturan Pemerintah Nomor 42 Tahun 2007 tentang Waralaba yang menyatakan bahwa penerima waralaba wajib mendaftarkan perjanjian waralaba.

Sama seperti tujuan dari pendaftaran prospektus penawaran waralaba, tujuan dari pendaftaran perjanjian waralaba yakni untuk mendapatkan Surat Tanda Pendaftaran Waralaba. Penerima waralaba yang berasal dari waralaba dalam negeri wajib mendaftarkan perjanjian waralaba ke kantor dinas yang bertanggungjawab di bidang perdagangan Provinsi DKI Jakarta atau Kabupaten/Kota atau Kantor Pelayanan Terpadu Satu Pintu setempat di seluruh Indonesia dengan mengisi formulir surat permohonan Surat Tanda Pendaftran Waralaba bagi penerima waralaba dalam negeri.

Pada saat penelitian ini dilakukan, penerima waralaba Bakso Tengkleng Mas Bambang belum mendaftarkan perjanjian waralaba kepada Kementerian Perdagangan. Hal ini dikarenakan ketidaktahuan dari penerima waralaba akan kewajiban untuk mendaftarkan perjanjian waralaba sebagaimana tercantum dalam Pasal 11 ayat (1) Peraturan Pemerintah Nomor 42 Tahun 2007 tentang Waralaba.

Sekalipun tidak menentukan syarat sahnya suatu perjanjian waralaba, prosedur mengenai pendaftaran waralaba tidak dapat dikesampingkan begitu saja. Dalam hal perjanjian waralaba dan prospektus penawaran waralaba tidak didaftarkan, maka terdapat sanksi yang dapat dijatuhkan sebagaimana dalam Pasal 16 ayat (1) Peraturan Pemerintah Nomor 42 Tahun 2007 tentang Waralaba. Sanksi yang diberikan dapat berupa sanksi administratif berupa peringatan tertulis dan sanksi administratif berupa denda. Sanksi berupa peringatan tertulis dapat diberikan paling banyak 3 (tiga) kali dalam tenggang waktu 2 (dua) minggu terhitung sejak tanggal surat peringatan sebelumnya diterbitkan. Sanksi berupa denda dikenakan kepada Pemberi waralaba yang tidak melakukan pendaftaran prospektus penawaran Waralaba atau Penerima waralaba yang tidak melakukan pendaftaran perjanjian Waralaba setelah diterbitkannya surat peringatan tertulis ketiga. Denda yang dikenakan paling banyak Rp. 100.000.000 (seratus juta rupiah).

Oleh karena itu, penerima dan pemberi waralaba sebaiknya mendaftarkan prospektus waralaba dan perjanjian waralaba. Pendaftaran ini akan bermanfaat bagi penerima waralaba karena akan memiliki perlindungan hukum yang kuat dan akan mendatangkan rasa percaya bagi calon penerima waralaba. Bagi penerima waralaba, pendaftaran perjanjian akan memberikan perlindungan dari tindakan kesewenangwenangan pemberi waralaba. 
2. Upaya Yang Dapat Ditempuh Oleh Para Pihak Dalam Hal Terjadi Wanprestasi Dalam Pelaksanaan Perjanjian Waralaba Bakso Tengkleng Mas Bambang

Pada kenyataannya, pelaksanaan prestasi tidak selalu berjalan dengan baik sesuai yang diperjanjikan, tak terkecuali pada perjanjian waralaba Bakso Tengkleng Mas Bambang. Tidak terpenuhinya prestasi biasa disebut sebagai wanprestasi. Wanprestasi merupakan suatu keadaan tidak terpenuhinya prestasi karena adanya kelalaian pihak yang seharusnya memenuhi kewajibannya tersebut. Wanprestasi dapat berupa 4 (empat) macam, yakni (Subekti, 2005: 1):

a. Tidak melakukan apa yang disanggupi akan dilakukannya;

b. Melaksanakan apa yang dijanjikannya tetapi tidak sebagaimana dijanjikan;

c. Melakukan apa yang dijanjikan tetapi terlambat;

d. Melakukan sesuatu yang menurut perjanjian tidak boleh dilakukan.

Berdasarkan data yang diperoleh dari responden, dalam pelaksanaan usaha waralaba sering terjadi keterlambatan pembayaran bahan baku oleh penerima waralaba. Setelah bahan baku sampai ke tangan penerima waralaba, seharusnya penerima waralaba melakukan pembayaran kepada pemberi waralaba. Pada faktanya pembayaran dilakukan setelah 2 (dua) sampai 4 (empat) kali faktur bahkan lebih. Tindakan tersebut dilakukan dengan alasan pendapatan yang terus berkurang sehingga lebih besar pengeluaran dilakukan oleh Cabang Rumah Makan Bakso Tengkleng Mas Bambang dari pada pemasukan yang dihasilkan.

Pasal 7 Perjanjian Waralaba Bakso Tengkleng Mas Bambang tentang BiayaBiaya hanya menyebutkan bahwa Penerima waralaba setuju membayar kepada Pemberi waralaba semua biaya dan iuran sesuai dengan perjanjian ini termasuk biaya tagihan tambahan atas semua produk atau jasa-jasa yang diberikan atau akan diberikan kepada Pemberi waralaba. Selebihnya mengenai tata cara pembayaran dan sanksi yang dijatuhkan apabila terjadi keterlambatan pembayaran, tidak diatur dalam perjanjian Bakso Tengkleng Mas Bambang.

Pemberi waralaba juga mendapati adanya penerima waralaba yang melakukan pembelian bahan baku mie yang bukan berasal dari Bakso Tengkleng Mas Bambang. Hal ini pernah dilakukan oleh salah satu penerima waralaba Rumah Makan Bakso Tengkleng Mas Bambang yang berada di Kabupaten Sukoharjo, Provinsi Jawa Tengah.

Pembelian bahan baku yang wajib dibeli dari Bakso Tengkleng Mas Bambang adalah bakso, mie, tengkleng, ayam kecap, kaldu, bumbu rempah, tulang kaki dan siomay (Hasil Wawancara dengan Bapak Anang Wibowo Manajer Operasional Bakso Tengkleng Mas Bambang). Perbuatan penerima waralaba yang mana melakukan pembelian bahan baku mie yang bukan berasal dari pemberi waralaba merupakan suatu bentuk wanprestasi menurut pemberi waralaba 
Zil Aidi dan Hasna Farida: Perlindungan Hukum Para Pihak Dalam Perjanjian Waralaba..

karena pemberi waralaba dianggap tidak melakukan apa yang disanggupi akan dilakukannya.

Pasal 5 ayat (6) perjanjian Waralaba Bakso Tengkleng Mas Bambang menyebutkan bahwa Pemberi waralaba berkewajiban untuk menyediakan bahan baku guna memasok bahan baku untuk operasional di setiap gerai Bakso Tengkleng Mas Bambang. Akan tetapi, dalam perjanjian waralaba Bakso Tengkleng Mas Bambang tidak tercantum kewajiban bagi penerima waralaba untuk melakukan pembelian bahan baku mie dari Bakso Tengkleng Mas Bambang. Hal ini mengakibatkan pembelian bahan baku yang bukan berasal dari pemberi waralaba menurut hemat penulis tidaklah dapat digolongkan sebagai suatu bentuk wanprestasi.

Peristiwa pembelian bahan baku mie yang bukan berasal dari penerima walaralaba dan keterlambatan pembayaran bahan baku oleh penerima waralaba tidak diatur dalam perjanjian waralaba Bakso Tengkleng Mas Bambang dan mengakibatkan kerugian terhadap pemberi waralaba karena salah satu sumber pendapatan pemberi waralaba yakni dari penjualan bahan baku. Hal ini dikarenakan pada Bakso Tengkleng Mas Bambang tidak terdapat royalty fee. Penerima waralaba cukup membayar satu kali pembayaran di awal sebesar nominal yang telah disepakati. Pendapatan pemberi waralaba selain dari pembayaran satu kali di awal yaitu dengan mengharuskan pembelian bahan baku yang berasal dari pemberi waralaba.
Apabila pemberi waralaba Bakso Tengkleng Mas Bambang mewajibkan pembelian bahan baku harus dari pemberi waralaba, maka perlu dilakukan perubahan isi perjanjian atau melalui addendum yang memuat tata cara pembayaran, kewajiban pembelian bahan baku dari pemberi waralaba, dan sanksi yang dijatuhkan apabila terjadi pelanggaran dalam perjanjian agar terdapat kepastian bagi pemberi waralaba dan penerima waralaba mengenai hak dan kewajiban yang harus dipenuhi.

Dalam perspektif yang berbeda, Pasal 5 ayat (1) perjanjian waralaba Bakso Tengkleng Mas Bambang, Pemberi waralaba berkewajiban untuk memberikan panduan operasional tata kelola kepada Penerima waralaba. Prestasi dengan berbuat sesuatu sebagai contoh dalam Pasal 5 ayat (7) dimana pemberi waralaba berkewajiban untuk melakukan program pemasaran secara nasional. Lebih lanjut, dalam Pasal 4 ayat (2), Penerima waralaba tidak diperkenankan memindahkan alamat rumah makan ke tempat lain tanpa persetujuan tertulis dari Pemberi waralaba.

Berdasarkan hasil wawancara yang dilakukan oleh penulis terhadap responden dari pihak penerima waralaba, terdapat wanprestasi yang dilakukan oleh pemberi waralaba yakni tidak menyelenggarakan program pelatihan untuk Penerima waralaba (penerima waralaba) secara berkesinambungan dan berkala paling sedikit 2 (dua) kali dalam setahun, dan tidak memberikan konsultasi 
gratis kepada Penerima waralaba (penerima waralaba) apabila gerai Penerima waralaba berada dalam keadaan kritis yang dapat menyebabkan tutupnya atau berhentinya bisnis milik Penerima waralaba.

Pemberi waralaba berkewajiban untuk menyelenggarakan program pelatihan untuk Penerima waralaba secara berkesinambungan dan berkala paling sedikit 2 (dua) kali dalam setahun. Akan tetapi, dalam praktiknya pemberi waralaba hanya menyelenggarakan program pelatihan 1 (satu) kali pada saat diawal pembukaan rumah makan.

Pemberi waralaba juga tidak melaksanakan kewajiban sebagaimana dalam Pasal 5 ayat (5) yakni tidak memberikan konsultasi gratis kepada Penerima waralaba apabila gerai Penerima waralaba berada dalam keadaan kritis yang dapat menyebabkan tutupnya atau berhentinya bisnis milik para Penerima waralaba. Banyak Rumah Makan Bakso Tengkleng Mas Bambang yang mengalami penurunan pendapatan sehingga membutuhkan solusi dari dan konsultasi dari pihak pemberi waralaba. Akan tetapi, keluhan dan permintaan dari penerima waralaba tidak ditanggapi oleh pihak pemberi waralaba.

Selain tercantum dalam perjanjian waralaba Bakso Tengkleng Mas Bambang, kewajiban untuk melakukan pembinaan juga tercantum dalam Pasal 8 Peraturan Menteri Perdagangan Nomor 7 Tahun 2013 tentang Pengembangan Kemitraan Dalam Waralaba Untuk Jenis Usaha Makanan dan Minuman dan Pasal
8 Peraturan Pemerintah Nomor 42 Tahun 2007 tentang Waralaba. Pasal 8 Peraturan Menteri Perdagangan Nomor 07/MDAG/PER/2013 tentang Pengembangan Kemitraan Dalam Waralaba Untuk Jenis Usaha Makanan dan Minuman menyebutkan bahwa pemberi waralaba untuk jenis usaha retoran, rumah makan, bar/rumah minum dan kafe wajib memberikan pembinaan kepada penerima waralaba dan/atau penyerta modal berupa pelatihan dan petunjuk pengelolaan usaha waralaba. Pasal 8 Peraturan Pemerintah Nomor 42 Tahun 2007 tentang Waralaba juga menyatakan bahwa pemberi waralaba wajib memberikan pembinaan dalam bentuk pelatihan, bimbingan operasional manajemen, pemasaran, penelitian, dan pengembangan kepada Penerima waralaba secara berkesinambungan.

Terhadap pelanggaran Pasal 8 Peraturan Menteri Perdagangan Nomor 07/M-DAG/PER/2013 tentang Pengembangan Kemitraan Dalam Waralaba Untuk Jenis Usaha Makanan dan Minuman, terdapat sanksi yang dapat dijatuhkan bagi pihak yang melanggar. Berdasarkan Pasal 11 Peraturan Menteri Perdagangan Republik Indonesia Nomor 58/M-DAG/PER/9/2014 tentang Perubahan Atas Peraturan Menteri Perdagangan Nomor 07/MDAG/PER/2013 tentang Pengembangan Kemitraan Dalam Waralaba Untuk Jenis Usaha Makanan dan Minuman, pemberi waralaba yang melanggar Pasal 8 Peraturan Menteri Perdagangan Nomor 07/M-DAG/PER/2013 tentang 
Zil Aidi dan Hasna Farida: Perlindungan Hukum Para Pihak Dalam Perjanjian Waralaba..

Pengembangan Kemitraan Dalam

Waralaba Untuk Jenis Usaha Makanan dan Minuman dapat dikenakan sanksi administratif secara bertahap berupa:

a. Peringatan tertulis paling banyak 3 (tiga) kali berturut-turut dengan tenggang waktu 2 (dua) minggu sejak tanggal surat peringatan oleh pejabat penerbit Surat Tanda Pendaftaran Waralaba;

b. Pemberhentian sementara Surat Tanda Pendaftaran Waralaba paling lama 2 (dua) bulan apabila tidak memenuhi ketentuan dalam peringatan tertulis sebagaimana dimaksud pada huruf a; dan

c. Pencabutan Surat Tanda Pendaftaran Waralaba apabila tidak memenuhi ketentuan sebagaimana dimaksud pada huruf $b$.

Tindakan wanprestasi membawa konsekuensi terhadap timbulnya hak pihak yang dirugikan untuk menuntut pihak yang melakukan wanprestasi untuk memberikan ganti rugi, sehingga oleh hukum diharapkan agar tidak ada satu pihak pun yang dirugikan karena wanprestasi tersebut (Fuady, 2001: 88).

Upaya penyelesaian yang dapat ditempuh oleh para pihak dalam hal terjadi wanprestasi dapat digolongkan sebagai bentuk perlindungan hokum bersifat represif. Bentuk represif lahir karena adanya sengketa yang harus diselesaikan. Hak yang dapat digugat oleh kreditur sebagaimana diatur dalam Pasal 1267 KUHPerdata yakni:

a. Pemenuhan perjanjian (nakoming); b. Ganti rugi (vervangende vergoeding);

c. Pembubaran, pemutusan, atau pembatalan perjanjian (ontbinding);

d. Pemenuhan perjanjian disertai dengan ganti rugi pelengkap (nakoming en anvvullend vergoeding);

e. Pembubaran perjanjian disertai dengan ganti rugi pelengkap (ontbinding en anvullend vergoeding).

Saat ini, pihak penerima waralaba hanya menginginkan agar pemberi waralaba dapat melaksanakan pemenuhan perjanjian yakni dengan menyelenggarakan program pelatihan untuk penerima waralaba secara berkesinambungan dan berkala paling sedikit 2 (dua) kali dalam setahun, dan memberikan konsultasi gratis kepada penerima waralaba apabila gerai penerima waralaba berada dalam keadaan kritis yang dapat menyebabkan tutupnya atau berhentinya bisnis Bakso Tengkleng Mas Bambang milik penerima waralaba. Tidak ada ganti rugi yang dituntut maupun pembatalan perjanjian.

Berdasarkan Pasal 13 Perjanjian Waralaba Bakso Tengkleng Mas Bambang, terdapat 2 (dua) mekanisme penyelesaian sengketa yang dapat dilakukan oleh pemberi waralaba dan penerima waralaba sebagaimana berikut:

"Apabila timbul sengketa diantara kedua belah pihak akibat perjanjian ini akan diselesaikan secara musyawarah dan mufakat. Apabila dalam musyawarah untuk mufakat tersebut tidak berhasil mencapai kesepakatan maka kedua belah pihak akan menyelesaikan secara hukum 
dan karenanya kedua belah pihak memilih domisili hukum yang tetap di kantor kepaniteraan Pengadilan Negeri yang disepakati."

Adapun penjelasan dari tiap mekanisme penyelesaian sengketa adalah sebagai berikut:

a. Penyelesaian melalui musyawarah

Bakso Tengkleng Mas Bambang dalam melakukan penyelesaian masalah mengutamakan penyelesaian secara damai melalui musyawarah untuk mencapai mufakat. Terhadap kelalaian yang dilakukan baik oleh penerima waralaba maupun pemberi waralaba selalu diselesaikan secara kekeluargaan terlebih dahulu. Para pihak akan bertemu dan membicarakan masalah untuk kemudian mencari solusi yang terbaik bagi kedua belah pihak.

b. Penyelesaian melalui jalur litigasi atau pengadilan

Manakala pemberi waralaba tidak memenuhi kewajiban yang telah disepakati oleh para pihak dalam kontrak waralaba, dan telah dinyatakan lalai namun tetap melalaikannya, maka pihak yang dirugikan dapat mengajukan gugatan kepada pihak yang melakukan wanprestasi. Gugatan wanprestasi diajukan di Pengadilan Negeri sesuai dengan kompetensi absolut dan relatif dalam hukum acara perdata.

Upaya penyelesaian melalui jalur litigasi atau pengadilan merupakan sarana akhir (ultimum remidium) manakala penyelesaian sengketa melalui cara-cara lain tidak mendapatkan hasil. Hingga saat ini penyelesaian sengketa di pada perjanjian waralaba ini dilakukan menggunakan asas itikad baik melalui musyawarah oleh para pihak. Belum ada penyelesaian sengketa melalui jalur litigasi atau pengadilan.

\section{SIMPULAN}

Bentuk perlindungan hukum yang diberikan berupa perlindungan hukum preventif dan represif. Perlindungan hukum secara preventif telah diberikan melalui Perjanjian Waralaba Bakso Tengkleng Mas Bambang yang memuat mengenai kewajiban masing-masing pihak yakni dalam Pasal 6 ayat (4), Pasal 6 ayat (5) dan Pasal 6 ayat (6) mengenai kewajiban untuk menjaga kerahasiaan, menjaga merek, dan menaati prosedur yang ditetapkan. Perlindungan hukum secara preventif juga tercantum dalam Pasal 1 angka 9 dan Pasal 11 mengenai larangan untuk menyajikan makanan dan minuman lain selain Bakso Tengkleng Mas Bambang serta rahasia dagang. Adapun, perlindungan hukum secara represif dilakukan melalui musyawarah untuk mencapai mufakat yang dilakukan oleh para pihak dalam menyelesaikan sengketa.

Upaya yang dapat ditempuh oleh para pihak dalam hal terjadi wanprestasi dalam pelaksanaan Perjanjian Waralaba Bakso Tengkleng Mas Bambang adalah musyawarah dan mufakat. Dalam hal musyawarah untuk mufakat tersebut tidak berhasil mencapai kesepakatan maka kedua belah pihak akan menyelesaikan secara hukum melalui jalur litigasi atau pengadilan. Sampai saat ini penyelesaian 
Zil Aidi dan Hasna Farida: Perlindungan Hukum Para Pihak Dalam Perjanjian Waralaba..

sengketa selalu dapat diselesaikan melalui musyawarah. Belum ada upaya penyelesaian sengketa melalui jalur litigasi atau pengadilan.

Penulis menyarankan para pihak dalam perjanjian waralaba diharapkan segera mendaftarkan prospektus pendaftaran waralaba dan mendaftarkan perjanjian waralaba agar mendapatkan STPW (Surat Tanda Pendaftaran Waralaba), serta melakukan amandemen atau addendum terhadap Perjanjian Waralaba Bakso Tengkleng Mas Bambang. Selain itu, dibutuhkan itikad baik dari para pihak dalam menjalankan seluruh klausula dalam perjanjian waralaba agar usaha yang dijalankan dapat terus berkembang.

\section{UCAPAN TERIMA KASIH}

Terima kasih yang sebesar-besarnya kepada semua pihak yang telah membantu kelancaran penulisan dan penelitian ini, terkhususnya kepada Bapak Anang Wibowo selaku Manajer Operasional Bakso Tengkleng Mas Bambang, dan juga para Responden selaku penerima waralaba Bakso Tengkleng Mas Bambang yang telah berkenan penulis wawancarai. Besar harapan kontribusi kecil ini dapat memberi kemanfaatan bagi industri bisnis waralaba di Indonesia.

\section{DAFTAR PUSTAKA}

\section{Buku-buku:}

Abdulkadir Muhammad, 1982, Hukum Perikatan, Alumni, Bandung.

Adrian Sutedi, 2008, Hukum Waralaba, Penerbit Ghalia Indonesia, Bogor.
Gunawan Widjaja, 2001, Waralaba, PT. Raja Grafindo Persada, Jakarta.

Kevin Kogin, 2014, Aspek Hukum Kontrak Waralaba: Kegiatan Usaha Jasa Makanan dan Minuman, PT. Tatanusa, Jakarta.

Maria S.W. Sumardjono, 2001, Pedoman Pembuatan Usulan Penelitian, Gramedia, Jakarta.

Munir Fuady, 2001, Hukum Kontrak (Dari Sudut Pandang Hukum Bisnis), PT. Citra Aditya Bakti.

Salim, 2007, Pengembangan Hukum Kontrak Diluar KUHPerdata, PT. RajaGrafindo Persada, Jakarta.

Subekti, 2005, Hukum Perjanjian, Intermasa, Jakarta.

Zainal Asikin, 2004, Pengantar Metode Penelitian Hukum, PT. Raja

Grafindo Persada, Jakarta.

\section{Artikel Jurnal:}

A.Yudha Harnoko, Ika Yunia Ratnawati, 2015, Asas Proporsional dalam Perjanjian Waralaba (Franchise), Jurnal Hukum Bisnis Vol. 1 No 1 April 2015, hlm 1-17.

Asuan, 2017, Eksistensi Waralaba (Franchise) Menurut Peraturan Pemerintah Nomor 42 Tahun 2007 sebagai Perjanjian Innominaat, Jurnal Hukum Universitas Palembang Vol.13 No. III, hlm 260-271.

Dewi Astuti, 2005, Kajian Bisnis Franchise Makanan di Indonesia, Jurnal Manajemen dan Kewirausahaan, Vol 7 No.1, hlm 83-97. 
Ferry R. Lasamahu, 2006, Perlindungan Hukum Terhadap Franchisee dalam Perjanjian Waralaba (studi kasus : Analisis Putusan Pengadilan Antara PT. Lingkar Natura Inti dan Natasha Kasakeyan), Jurnal Hukum dan Pembangunan Tahun ke-36 No. 3, hlm 306-329.

Norman Syahdar Idrus, 2017, Aspek Hukum Perjanjian Waralaba (Franchise) Dalam Perspektif Hukum Perdata dan Hukum Islam, Jurnal Yuridis Vol.4 No. 1, hlm 2845.

Putu Prasmita Sari, I Gusti Ngurah Parwata, 2016, Perlindungan Hukum Para Pihak Dalam Perjanjian Bisnis Franchise, Jurnal Kertha Semaya, Vol. 04 No. 05, hlm 1-6.

Rizky Aditya Setiawan, Oscar Valentino, Jujuk Herawati, 2011, Menjamurnya Usaha Franchise di
Yogyakarta (Tahu Bulat Tiara) Jurnal Manajemen Vol 1 No.1, hlm 50-53.

\section{Artikel Internet:}

Bisnis Waralaba Tumbuh Pesat di Indonesia, https://economy.okezone.com/read/ 2016/05/17/320/1390833/bisniswaralaba-tumbuh-pesat-diindonesia, diakses pada 7 Maret 2019.

Ghoida Rahmah, Omzet Industri Waralaba Nasional Mencapai 172 Triliun, https://bisnis.tempo.co/read/823138/ omzet-industri-waralaba-nasionalmencapai-rp-172-triliun, diakses pada $\quad 10 \quad$ Maret 2019. 